\title{
Nauplius
}

The Journal OF The

Brazilian Crustacean Society

e-ISSN 2358-2936

www.scielo.br/nau www.crustacea.org.br

\section{On two species of Periclimenaeus Borradaile, 1915 (Caridea: Palaemonidae) from colonial tunicates in the southwestern Atlantic}

Luciane Augusto de Azevedo Ferreira' ${ }^{1}$ (D) orcid.org/0000-0003-1683-9962

Paulo P.G. Pachelle ${ }^{1}$ (D) orcid.org/0000-0003-0093-9352

Sandra Vieira Paiva² (D) orcid.org/0000-0002-8705-2836

1 Museu de Zoologia, Universidade de São Paulo. Avenida Nazaré, 481, Ipiranga, 04263-000, São Paulo, São Paulo, Brazil.

2 Laboratório de Plâncton, Instituto de Ciências do Mar (Labomar).

Universidade Federal do Ceará, Fortaleza, Ceará, Brazil.

ZOOBANK: http://zoobank.org/urn:lsid:zoobank.org:pub:546DD20D-B566-4EE4A340-E8948748CDA8

\section{Abstract}

Two species of the palaemonid genus Periclimenaeus Borradaile, 1915, $P$. ascidiarum Holthuis, 1951 and $P$. maxillulidens (Schmitt, 1936), are reported from the offshore Escalvada Island, Espírito Santo, Brazil. The location represents a new southernmost record for these species in the western Atlantic. Both species were found inside an undescribed tunicate species of Diplosoma, dwelling inside the circulatory channels, among the zooid clusters. Although P. ascidiarum is known to occur in tunicates, the finding of the rare $P$. maxillulidens inside an ascidian host represents the first record of this association. Illustrations for both species and a taxonomic key for the southwestern Atlantic Periclimenaeus are provided based on the present material and literature records.

\section{KEYWORDS}

Ascidiacea, biodiversity, caridean shrimps, ecology, South Atlantic

CORRESPONDING AUTHOR Luciane Augusto de Azevedo Ferreira lucianeaaf@gmail.com

SUBMITTED 08 October 2019 ACCEPTED 05 May 2020 PUBLISHED 03 July 2020

DOI $10.1590 / 2358-2936 e 2020024$

\section{(cc) BY}

All content of the journal, except where identified, is licensed under a Creative Commons attribution-type BY.

Nauplius, 28: e2020024

\section{INTRODUCTION}

Currently composed of 83 species worldwide, Periclimenaeus Borradaile, 1915 is a specious genus within the Palaemonidae (Bruce, 2011; 2012a; 2012b; 2012c; 2013; 2014a; 2014b; 2014c; 2014d; De Grave and Fransen, 2011; Ďuriš et al., 2011; Ramos-Tafur and Lemaitre, 2017). Among the Atlantic palaemonids, the genus is readily recognized by the well-developed, highly asymmetrical second pereopods with snapping mechanism on the 
major chela (molar process on the dactylus and opposing fossa on the fixed finger), presence of an antennal tooth, absence of both hepatic and epigastric teeth, supraorbital tooth usually absent (when present, small), and a well-developed scaphocerite (Bruce, 1995).

Periclimenaeus species are typically found in cryptic habitats, dwelling inside sponge and ascidian hosts, and are most abundant in shallow tropical waters (Bruce, 2013). Out of the 14 species known from the western Atlantic, eight are reported as sponge-associated, one as ascidian-associated and the remaining five species have no host records (see Tab. 1).

In Brazil, the genus was hitherto represented by only seven species: Periclimenaeus ascidiarum Holthuis, 1951, Periclimenaeus atlanticus (Rathbun, 1901), Periclimenaeus brucei Cardoso and Young, 2007, Periclimenaeus caraibicus Holthuis, 1951, Periclimenaeus crosnieri Cardoso and Young,
2007, Periclimenaeus pearsei (Schmitt, 1932), and Periclimenaeus perlatus (Boone, 1930), all restricted to the northernmost coast of the country (Cardoso and Young, 2007; Souza et al., 2011; Vieira et al., 2012). Interestingly, P. atlanticus, originally reported from Paraíba by Young (1986), was missing in subsequent major checklists (e.g., Ramos-Porto and Coelho, 1998; Coelho et al., 2006; Vieira et al., 2012), and only briefly mentioned by Cardoso and Young (2007: 296). Although Young (1986) did not provide illustrations or a proper taxonomic treatment for his material, the identity of his specimens was confirmed by D. Grangeiro and M.L. Christoffersen (pers. comm.) through the examination of some of Young's (1986) vouchers deposited in the carcinological collection of the Universidade Federal da Paraíba, Paraíba, Brazil.

During ascidian samplings in Escalvada Island (Espírito Santo, Brazil), specimens of $P$. ascidiarum and P. maxillulidens (Schmitt, 1936) were retrieved

Table 1. List of hosts for the western Atlantic Periclimenaeus Borradaile, 1915 based on literature records. (?) - Host unknown; * - Species previously reported from Brazil

\begin{tabular}{|c|c|c|c|}
\hline Periclimenaeus species & Host type & Host identification & References \\
\hline P. ascidiarum Holthuis, $1951^{*}$ & Ascidiacea & Unknown & Holthuis (1951): 82 \\
\hline P. atlanticus (Rathbun, 1901) & (?) Coral and turtle-grass beds & Unknown & $\begin{array}{l}\text { Holthuis (1951): 84; Chace (1972): } \\
\qquad 26\end{array}$ \\
\hline P. bredini Chace, 1972 & $\begin{array}{l}\text { (?) Calcareous mudflats } \\
\text { and epibiont growth on } \\
\text { mangrove roots }\end{array}$ & Unknown & $\begin{array}{l}\text { Chace (1972): 28; Pachelle et al. } \\
\text { (2018): } 131\end{array}$ \\
\hline $\begin{array}{l}\text { P. brucei Cardoso and Young, } \\
2007^{*}\end{array}$ & Porifera & Ircinia sp. (Irciniidae) & Cardoso and Young (2007): 302 \\
\hline P. caraibicus Holthuis, $1951^{*}$ & (?) Coral reef and turtle-grass beds & Unknown & $\begin{array}{l}\text { Holthuis (1951): 113; Chace } \\
\text { (1972): 28; Vieira et al. (2012): } 14\end{array}$ \\
\hline P. chacei Abele, 1971 & (?) Coral rubble & Unknown & Abele (1971): 38 \\
\hline $\begin{array}{l}\text { P. crosnieri Cardoso and } \\
\text { Young, } 2007^{*}\end{array}$ & Porifera & Unknown & Cardoso and Young (2007): 309 \\
\hline $\begin{array}{l}\text { P. maxillulidens (Schmitt, } \\
\text { 1936) }\end{array}$ & $\begin{array}{l}\text { (?) Epibiont growth on mangrove } \\
\text { roots }\end{array}$ & Unknown & $\begin{array}{l}\text { Santana-Moreno et al. (2013): 231; } \\
\quad \text { Pachelle et al. (2018): } 132\end{array}$ \\
\hline $\begin{array}{l}\text { P. mcmichaeli Ramos-Tafur } \\
\text { and Lemaitre, } 2017\end{array}$ & Porifera? & Unknown & $\begin{array}{l}\text { Ramos-Tafur and Lemaitre (2017): } \\
\qquad 501\end{array}$ \\
\hline P. pearsei (Schmitt, 1932)* & Porifera & $\begin{array}{l}\text { Spongia officinalis Linnaeus (Spongiidae) and Ircinia } \\
\text { strobilina (Lamarck) (Irciniidae) }\end{array}$ & $\begin{array}{l}\text { Chace (1972): 29; Vieira et al. } \\
\text { (2012): 18; Santana-Moreno et al. } \\
\text { (2013): } 232\end{array}$ \\
\hline $\begin{array}{l}\text { P. pectinidactylus Ďuriš, Horká } \\
\text { and Sandford, } 2009\end{array}$ & Porifera & Smenospongia sp.? (Thorectidae) & Ďuriš et al. (2009): 32 \\
\hline P. perlatus (Boone, 1930)* & Porifera & Unknown & $\begin{array}{l}\text { Holthuis (1951): 103; Ramos-Porto } \\
\text { and Coelho (1998): } 338\end{array}$ \\
\hline P. schmitti Holthuis, 1951 & Porifera & $\begin{array}{c}\text { Aplysina fistularis (Pallas) (Aplysinidae), Lissodendoryx } \\
\text { colombiensis Zea and van Soest (Coelosphaeridae), } \\
\text { Monanchora arbuscula (Duchassaing and Micheloti) } \\
\text { (Crambeidae) and Xestospongia rosariensis Zea and } \\
\text { Rützler (Petrosiidae) }\end{array}$ & $\begin{array}{l}\text { De Grave and Anker (2017): } 28 \text {; } \\
\text { Santana-Moreno et al. (2013): } 232\end{array}$ \\
\hline P. wilsoni (Hay, 1917) & Porifera & Unknown & $\begin{array}{l}\text { Holthuis (1951): 106; Ramos-Tafur } \\
\text { and Lemaitre (2017): } 501\end{array}$ \\
\hline
\end{tabular}


from two colonies of an undescribed species of Diplosoma Macdonald (Ascidiacea: Didemnidae) (S. Vieira, pers. comm.). The material represents the southernmost record of both shrimp species in the southwestern Atlantic Ocean and the first host record for $P$. maxillulidens in the literature.

\section{Material And Methods}

The shrimps were extracted from two colonies of the ascidian Diplosoma sp. associated with coral rubble obtained by scuba diving at approximately 15 $m$ depth on the northernmost part of the Escalvada Island, Espírito Santo, Brazil. The tunicate hosts were preserved in $10 \%$ formaldehyde in sea water and deposited in the Ascidiacea collection of the Zoology Department at Universidade Federal do Paraná, Paraná, Brazil (DZUP).

The shrimps were extracted from the ascidian's circulatory channels and preserved in $70 \%$ ethanol; subsequently, they were studied and deposited in the carcinological collection of the Museu de Zoologia, Universidade de São Paulo (MZUSP). The shrimps were drawn under a stereomicroscope equipped with a camera lucida to illustrate the most important taxonomic characters. Carapace length ( $\mathrm{CL}$, in $\mathrm{mm}$ ) was used as standard measurement for the shrimps, measured from the level of the posterior orbital margin to the posterior margin in the midline of the carapace.

\section{Systematics}

\section{Palaemonidae Rafinesque, 1815}

Periclimenaeus Borradaile, 1915

\section{Periclimenaeus ascidiarum Holthuis, 1951}

(Figs. 1-3)

Periclimenaeus ascidiarum Holthuis, 1951: 80, pl. 22, figs. g-l, pl. 23, figs. a-i.- Chace, 1972: 25, 26. - Coelho and Ramos, 1972: 146._- RamosPorto, 1980: 297. - Abele and Kim, 1986: 11, 89.- Ramos-Porto and Coelho, 1990: 105.-
Ramos-Porto and Coelho, 1998: 337.- Coelho et al., 2006: 50, tab. 3. - Souza et al., 2011: 44.Vieira et al., 2012: 13, fig. 7 (map).—-Ramos-Tafur and Lemaitre, 2017: 505 (key).- Pachelle et al., 2018: 130, fig. 2 .

Material examined. Brazil, Espírito Santo, off Vitória, Escalvada Island, 2041'55.3”S 40²4'20.8”W, scuba dive, $15 \mathrm{~m}$ depth, coral rubble, inside Diplosoma sp. (Fig. 4), coll. Sandra Vieira Paiva, 29 March 2017: 1 ovigerous female, $2.7 \mathrm{~mm}$ CL, MZUSP 39106; 1 ovigerous female, $2.7 \mathrm{~mm}$ CL, MZUSP 39107.

Distribution. Western Atlantic: USA (Florida), Colombia (Cape de La Vela), Dominica, Cuba (Batabanó Gulf), Panama (Bocas del Toro) and Brazil (Maranhão, Ceará, Pernambuco, Espírito Santo) (Holthuis, 1951; Chace, 1972; Vieira et al., 2012; Pachelle et al., 2018; present study).

Remarks. The morphological characters in our specimens agree well with those described by Holthuis (1951), including (i) shape and armature of the rostrum (Fig. 1A), (ii) first article of antennular peduncle with distolateral angle produced into small tooth (Fig. 1C), (iii) scaphocerite twice as long as broad, with a distinct lateral tooth (Fig. 1D), (iv) proportions of the first pereopod (Fig. 1E); (v) overall shape and armature of the second pereopods (Fig. 2), and (vi) pereopods 3-5 with dactyli distally biunguiculate and bearing an additional proximoventral tooth (Fig. 3B, D, F).

Holthuis (1951) described P. ascidiarum based on specimens associated with unidentified ascidians from Florida (USA) and Cape la Vela (Colombia). Since then, the species has been reported from several localities in the Caribbean and Brazil, but with no mention of an ascidian host (Vieira et al., 2012). The new material suggests that $P$. ascidiarum occurs in colonial ascidians of the genus Diplosoma; however, the range of host species remains to be investigated. The present material also represents the first record of P. ascidiarum in Espírito Santo, extending considerably its known southern distribution in the Atlantic Ocean from Pernambuco $\left(8-9^{\circ} \mathrm{S}\right)$ to Escalvada Island $\left(20^{\circ} \mathrm{S}\right)$. 
A
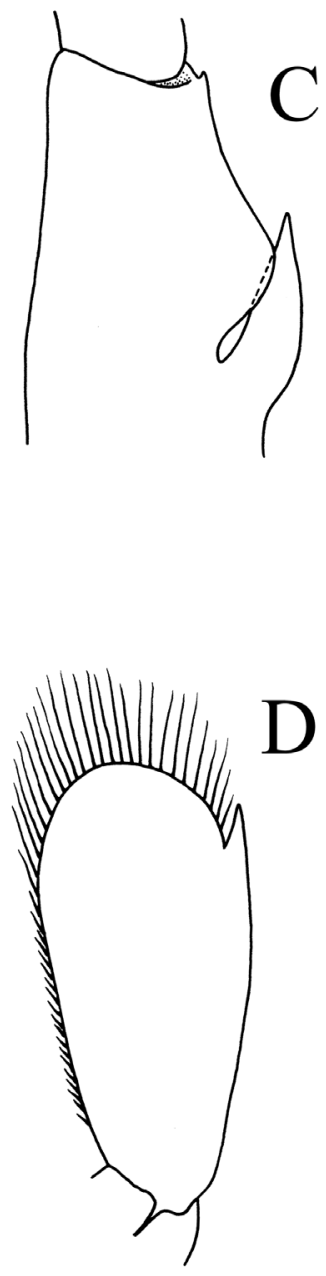

$\mathrm{D}$
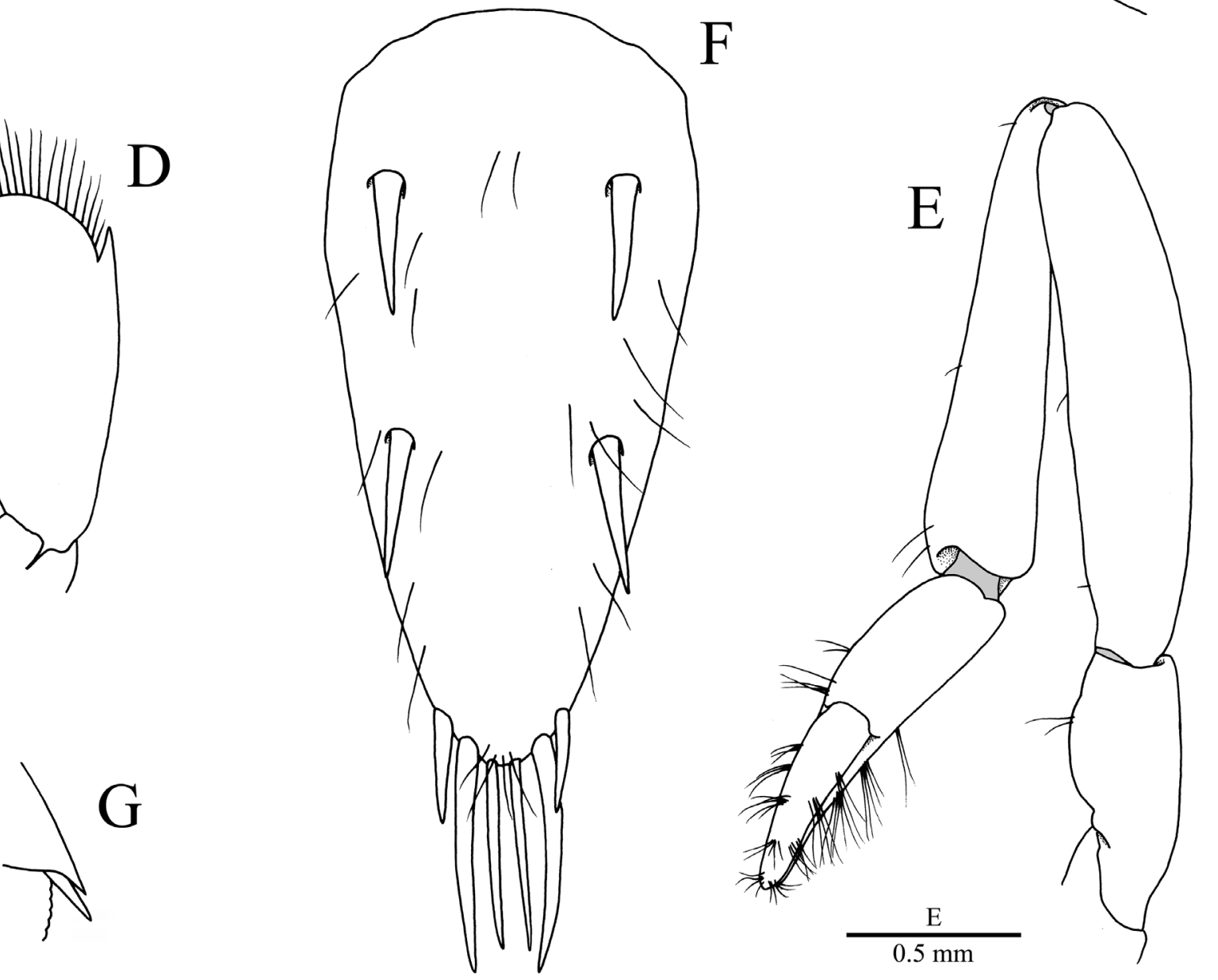

Figure 1. Periclimenaeus ascidiarum Holthuis, 1951, ovigerous female, $2.7 \mathrm{~mm}$ CL, MZUSP 39106: (A) rostrum, lateral view; (B) frontal margin and cephalic appendages, lateral view; (C) right antennule, first article of peduncle, dorsal view; (D) right scaphocerite, dorsal view; (E) left first pereopod, lateral view; (F) telson, dorsal view; (G) right uropod, diaeresis, dorsal view. 

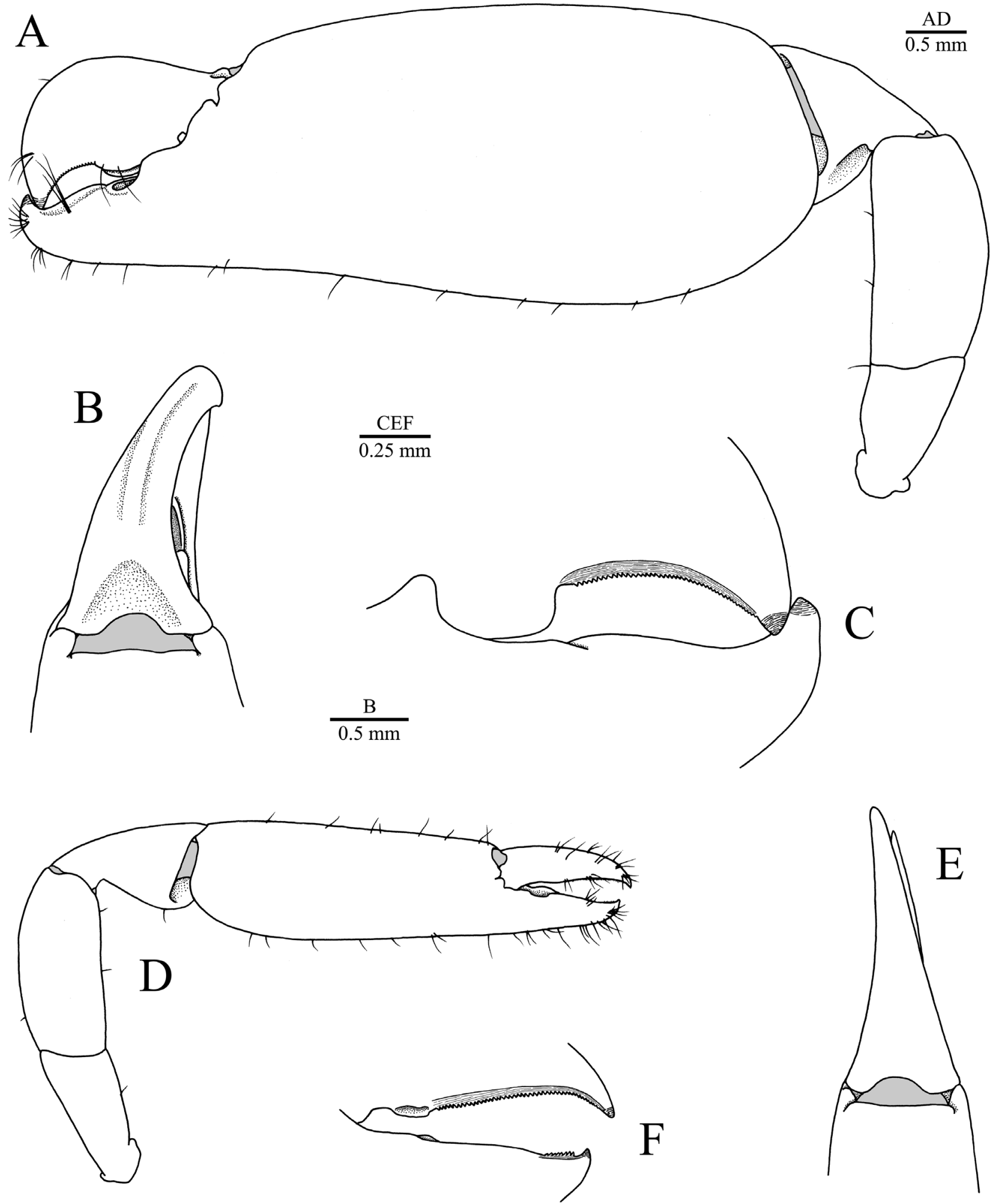

Figure 2. Periclimenaeus ascidiarum Holthuis, 1951, ovigerous female, $2.7 \mathrm{~mm}$ CL, MZUSP 39106: (A) major (left) second pereopod, lateral view; (B) same, fingers, dorsal view; (C) same, cutting edges, mesial view; (D) minor (right) second pereopod, lateral view; (E) same, fingers, dorsal view; (F) same, cutting edges, lateral view. 


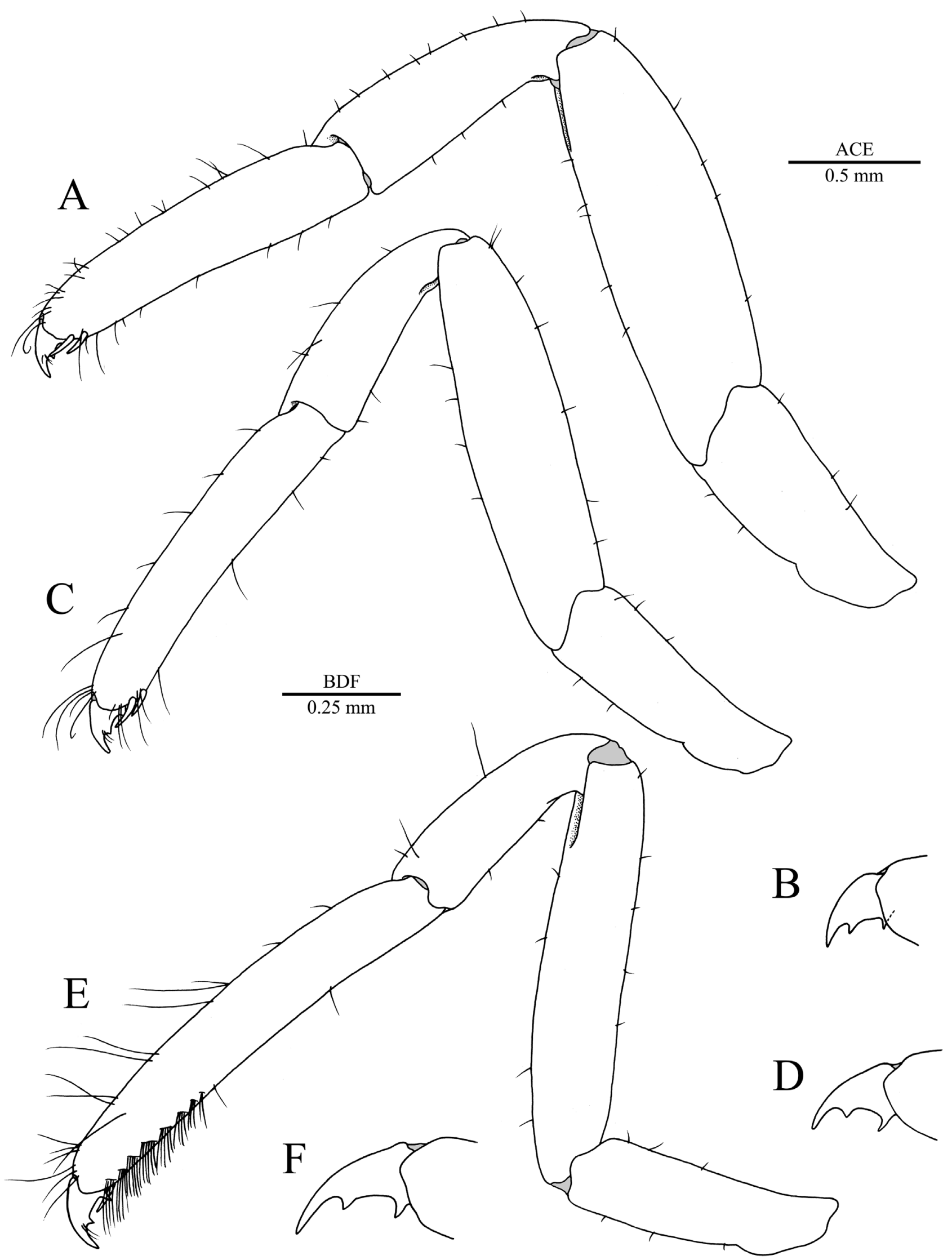

Figure 3. Periclimenaeus ascidiarum Holthuis, 1951, ovigerous female, $2.7 \mathrm{~mm}$ CL, MZUSP 39106: (A) left third pereopod, lateral view; (B) same, dactylus, lateral view; (C) left fourth pereopod, lateral view; (D) same, dactylus, lateral view; (E) left fifth pereopod, lateral view; (F) same, dactylus, lateral view. 


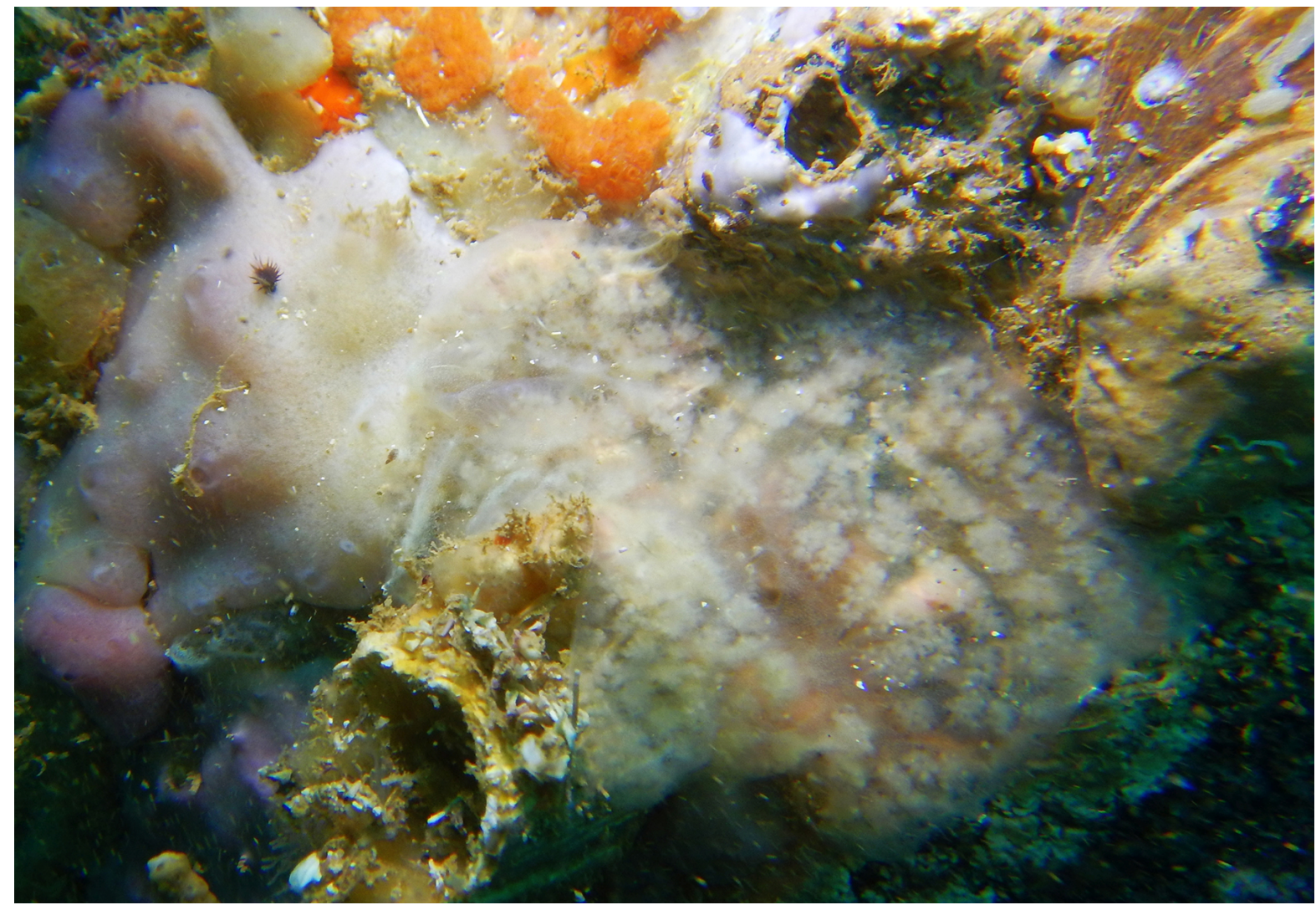

Figure 4. The ascidian host, Diplosoma sp. (Didemnidae), at Ilha Escalvada, Espírito Santo (Brazil), photographed in situ. Note the spaces between the zooid clusters where the shrimps were dwelling.

\section{Periclimenaeus maxillulidens (Schmitt, 1936)}

(Figs. 5-7)

Periclimenes maxillulidens Schmitt, 1936: 371, pl. 13, fig. 3a-o.

Periclimenaeus maxillulidens.- Holthuis, 1951: 87, pl. 26. - Abele and Kim, 1986: 11, 90.- Chace, 1972: 28.- Cardoso and Young, 2007: 295 (key), 296.- Santana-Moreno et al., 2013: 231, fig. 2G.Ramos-Tafur and Lemaitre, 2017: 505 (key) .Pachelle et al., 2018: 132.

Material examined. Brazil, Espírito Santo, off Vitória, Escalvada Island, 2041'55.3”S 40²4’20.8”W, scuba dive, $15 \mathrm{~m}$ depth, coral rubble, inside Diplosoma sp. (Fig. 4), coll. Sandra Vieira Paiva, 29 March 2017: 1 ovigerous female, $3.7 \mathrm{~mm}$ CL, MZUSP 39108.

Distribution. Western Atlantic: USA (Florida), Mexico (Yucatan), Bonaire, Panama (Bocas del Toro) and Brazil (Espírito Santo) (Schmitt, 1936; Holthuis,
1951; Santana-Moreno et al., 2013; Pachelle et al., 2018; present study).

Remarks. Schmitt (1936) described P. maxillulidens (as Periclimenes maxillulidens) based on one male collected in Bonaire. Afterwards, the species was only reported from USA (Florida), Mexico (Yucatan) and Panama (Bocas del Toro) (Holthuis, 1951; SantanaMoreno et al., 2013; Pachelle et al., 2018). The present female from Escalvada Island represents the fourth record of this rare species and its first record in Brazil and the southwestern Atlantic Ocean.

Our specimen agrees well with the specimens described and illustrated in Schmitt (1936: pl. 13) and Holthuis (1951:pl.26), including(i) shape and armature of the rostrum (Fig. 5A), (ii) first article of antennular peduncle with distolateral angle blunt, lacking a tooth (Fig. 5C), (iii) scaphocerite wider distally, with a small lateral tooth (Fig. 5D), (iv) proportions of the first pereopod (Fig. 5E), (v) overall shape and armature of the major second pereopod (Fig. 6A-C), and (vi) pereopods 3-5 with dactyli simple, lacking both subdistal and proximoventral teeth (Fig. 7B, D, F). 


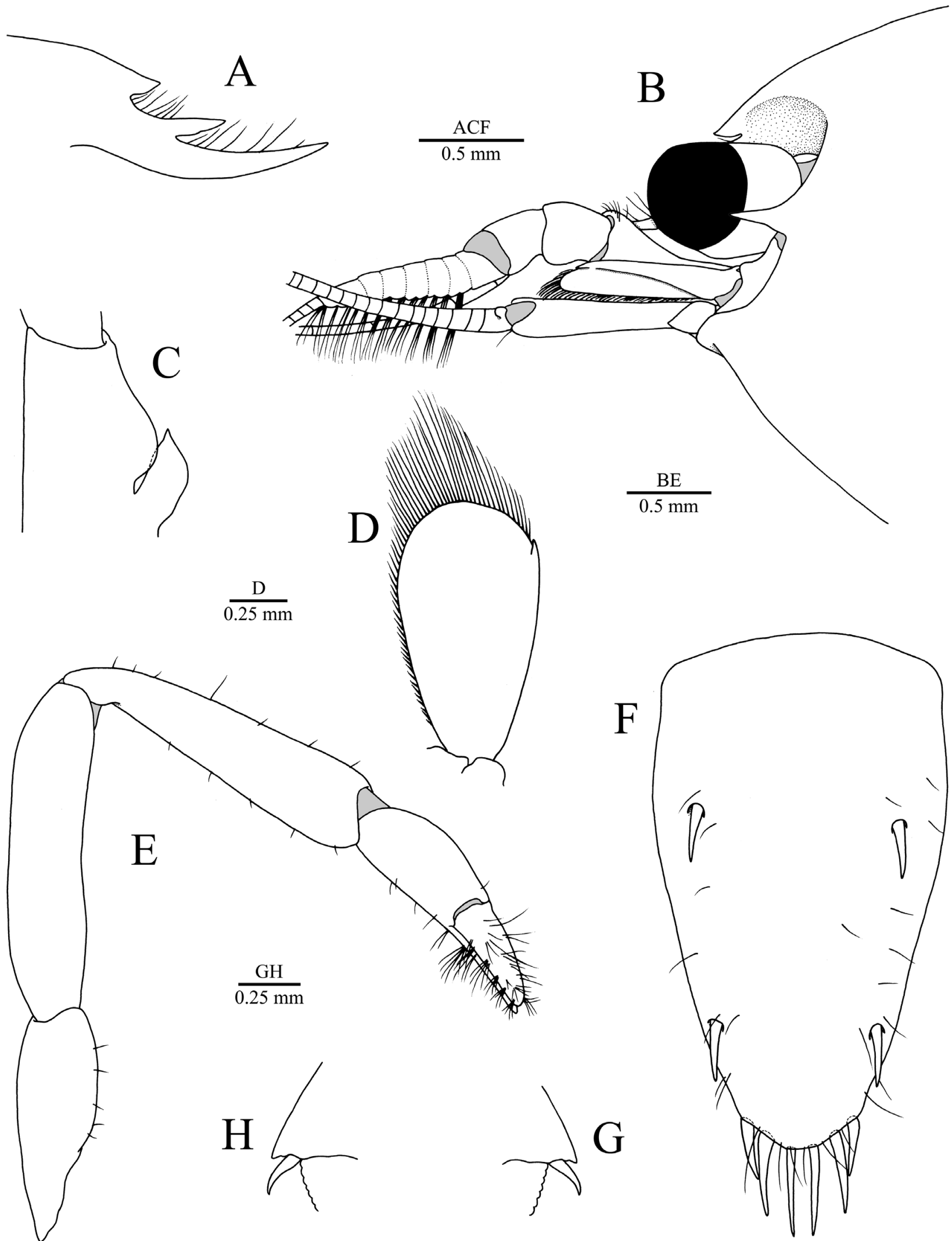

Figure 5. Periclimenaeus maxillulidens (Schmitt, 1936), ovigerous female, $3.7 \mathrm{~mm} \mathrm{CL}$, MZUSP 39108: (A) rostrum, lateral view; (B) frontal margin and cephalic appendages, lateral view; (C) right antennule, first article of peduncle, dorsal view; (D) right scaphocerite, dorsal view; (E) right first pereopod, lateral view; (F) telson, dorsal view; (G, H) right and left uropods, respectively, diaeresis, dorsal view. 


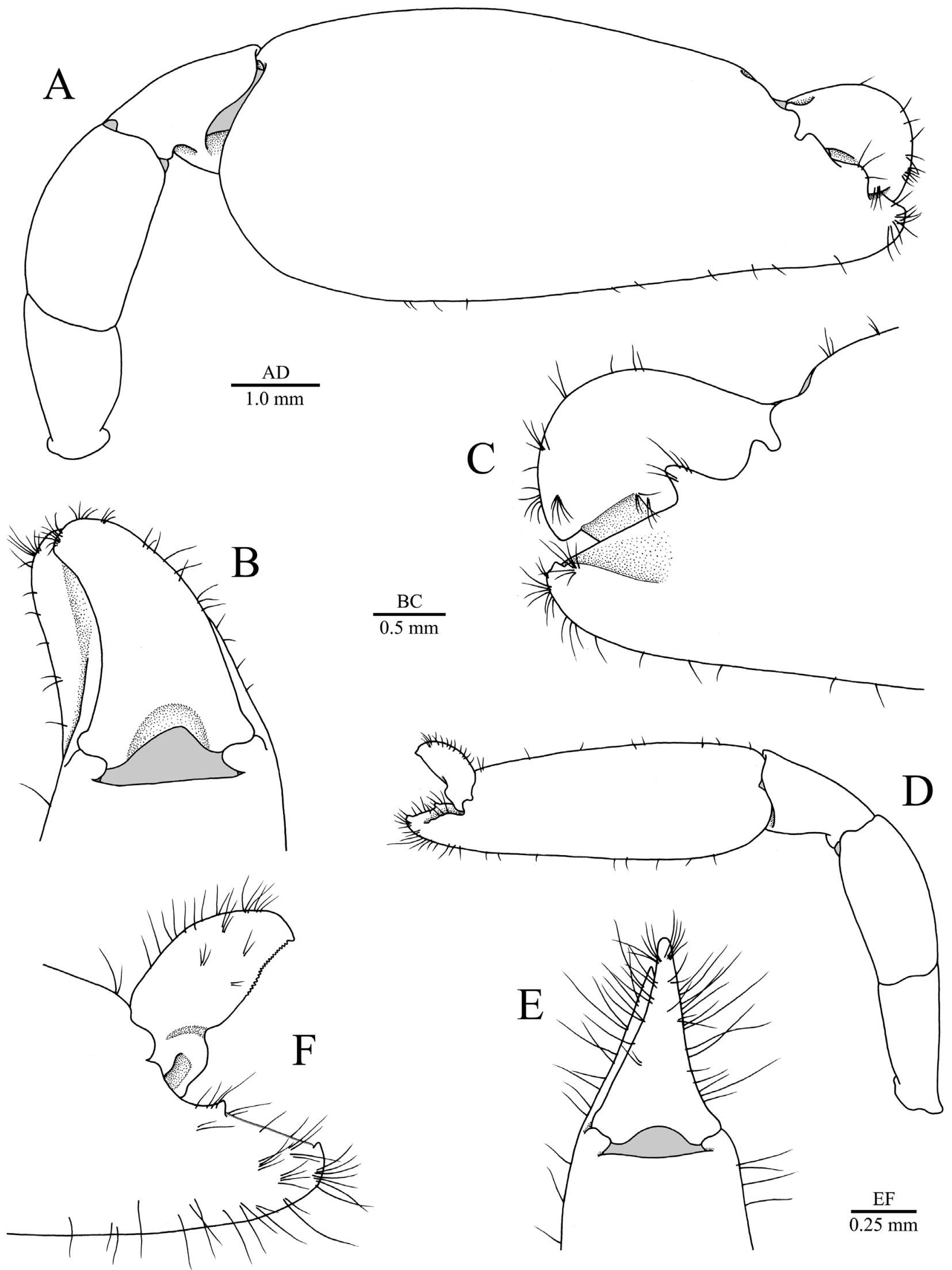

Figure 6. Periclimenaeus maxillulidens (Schmitt, 1936), ovigerous female, $3.7 \mathrm{~mm} \mathrm{CL}$, MZUSP 39108: (A) major (right) second pereopod, lateral view; (B) same, fingers, dorsal view; (C) same, mesial view; (D) minor (left) second pereopod, lateral view; (E) same, fingers, dorsal view; (F) same, mesial view. 


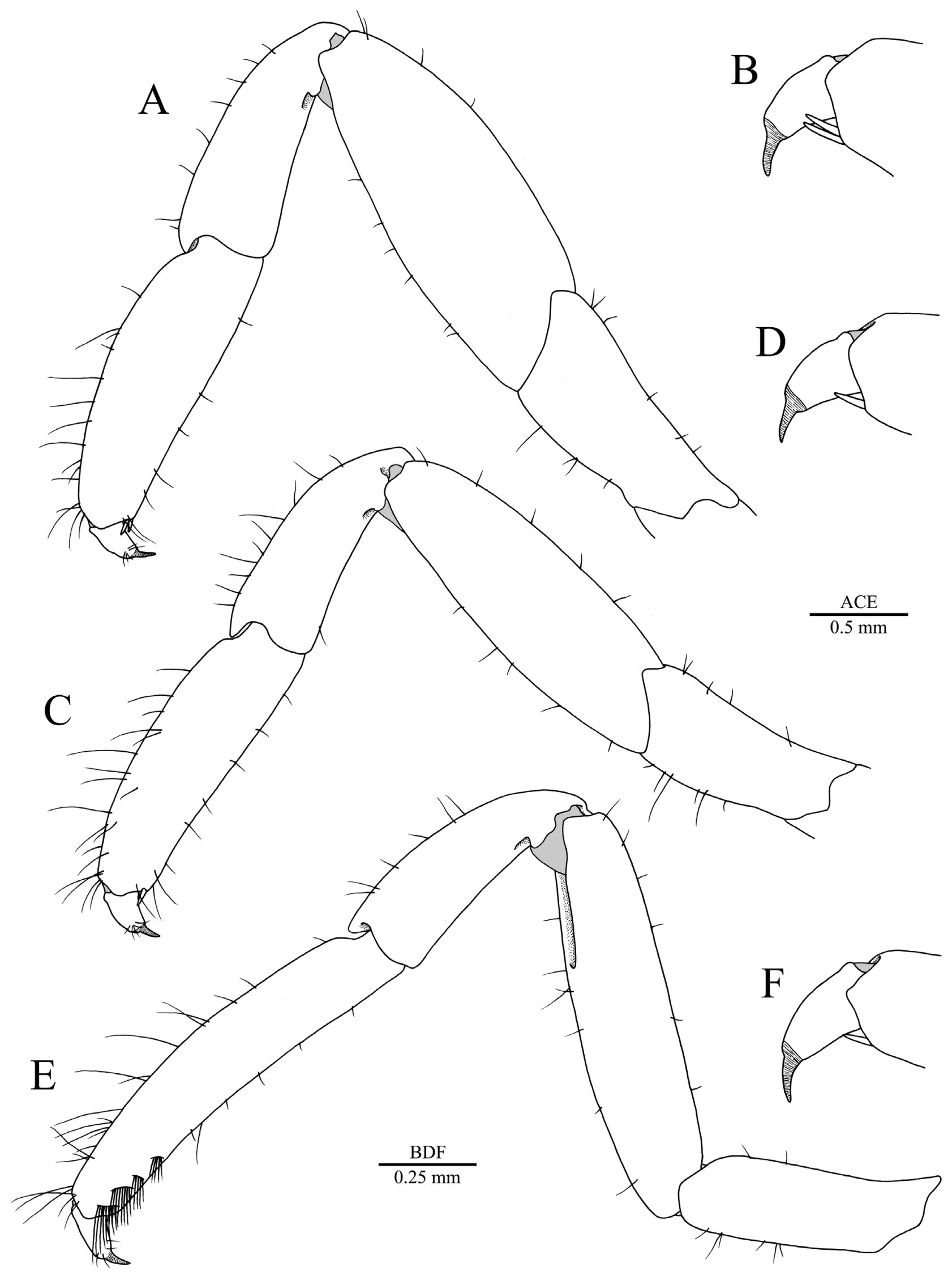

Figure 7. Periclimenaeus maxillulidens (Schmitt, 1936), ovigerous female, $3.7 \mathrm{~mm} \mathrm{CL}$, MZUSP 39108: (A) left third pereopod, lateral view; (B) same, dactylus, lateral view; (C) left fourth pereopod, lateral view; (D) same, dactylus, lateral view; (E) left fifth pereopod, lateral view; (F) same, dactylus, lateral view. 
The minor second pereopod, herein illustrated for the first time for the species (Fig. 6D-F), lacks granules on its surface, but is furnished with setae, which are more abundant on the chela fingers. The fingers are slightly curved inwards; the cutting edge of the fixed finger has a small triangular tooth on its proximal half and a series of tiny teeth on the distal half; the dactylus has a wide, laterally excavated process proximally, separated from the rest of the cutting edge by a sinus; cutting edge distally serrated (Fig. 6F).

According to Holthuis (1951), P. maxillulidens is morphologically very similar to two other Atlantic species, P. atlanticus and P. schmitti Holthuis, 1951. Periclimenaeus maxillulidens, however, can be readily separated from both species by the combination of three morphological characters: (i) shape and armature of rostrum (1-2 dorsal teeth in $P$. maxillulidens and $P$. schmitti, 4 teeth in P. atlanticus; cf. Holthuis, 1951: pl. 24, fig. b; Fig. 5A), (ii) armature of the scaphocerite (blunt in P.schmitti, with small tooth in P. maxillulidens, with distinct tooth in P. atlanticus; cf. Holthuis, 1951: pl.24, fig. e; pl. 27, fig. c; Fig. 5D), and (iii) the shape of pereopods 3-5 dactyli (simple in P. maxillulidens and P. atlanticus, biunguiculate in P. schmitti; cf. Holthuis, 1951: pl. 24, fig. o; pl. 27, fig. m; Fig. 7B, D, F).

Although most species of Periclimenaeus are known to associate with sponges and ascidians, the hosts for several species are either unknown or reported as unidentified sponges or ascidians (Holthuis, 1951; Bruce, 2006; Fransen, 2006; Dobson et al., 2016). Periclimenaeus maxillulidens has been reported from sandy debris (Schmitt, 1936), broken shells, gravel, sand and coral (Holthuis, 1951; Santana-Moreno et al., 2013). Pachelle et al. (2018) reported a single ovigerous female of $P$. maxillulidens in epibiotic growth on mangrove roots, but without specifying whether the specimen was collected inside sponges or ascidians. Therefore, the present study confirms that the species is, at least, associated with colonial ascidians of the genus Diplosoma (Fig. 4).
Identification key for the species of Periclimenaeus from the southwestern Atlantic

1a. Pereopods 3-5 with dactyli simple.........2 1b. Pereopods 3-5 with dactyli biunguiculate....3

2a. Rostrum straight, dorsal margin with 4 teeth; scaphocerite with lateral tooth distinct, strong...... .P. atlanticus

[Brazil: Paraíba]

2b. Rostrum sinuous, dorsal margin with 2-3 teeth; scaphocerite with lateral tooth subtle, weak........ .P. maxillulidens

[Brazil: Espírito Santo (Escalvada Island)]

3a. Rostrum with a ventral tooth; carapace with small supraorbital tooth or acute tubercle; scaphocerite with lateral tooth distinct, clearly overreaching blade; dactyli of pereopods 3-5 with unguis ventrally serrulate......................... caraibicus

[Brazil: Rio Grande do Norte (Atol das Rocas)] 3 b. Rostrum with ventral margin unarmed; orbital region of carapace smooth; scaphocerite with lateral tooth not as distinct, at most reaching the distal margin of the blade; dactyli of pereopods 3-5 with unguis ventrally smooth...................4

4a. Telson with both pairs of dorsal spines inserted in the anterior half of telson; outer pair of distal spines of telson removed from the distal margin, inserted more proximally than the remaining two distal pairs of spines ..............................

4b. Telson with posterior pair of dorsal spines inserted in the posterior half of telson; outer pair of distal spines of telson placed in the distal margin, in line with the remaining two distal pairs of spines............7

5a. Rostrum very high, dorsal teeth large; pereopod 1 carpus long, almost twice as long as chela........ .P.perlatus

[Brazil: Ceará, Paraíba, Pernambuco] 
5b. Rostrum not very high, dorsal teeth mediumsized; pereopod 1 carpus short, slightly longer than chela..................................6

6a. Carapace not inflated; second pereopods with palm furnished with numerous granules.......... P. brucei

[Brazil: Rio Grande do Norte (Atol das Rocas)] 6b. Carapace inflated; second pereopods chelae smooth, without granules............... crosnieri

[Brazil: Rio Grande do Norte (Atol das Rocas)]

7a. Rostrum long, distinctly overreaching the corneas; stylocerite slender, tip acute; dactylus of both second pereopods with cutting edge serrated near apex; minor second pereopod fingers serrated near apex; propodus of pereopod 3 with ventral spines restricted to the distoventral angle.................P. ascidiarum

[Brazil: Maranhão, Ceará, Pernambuco, Espírito Santo (Escalvada Island)]

$7 \mathrm{~b}$. Rostrum short, not reaching the distal margin of the corneas; stylocerite broad, tip triangular; dactylus of both second pereopods with cutting edge smooth near apex; minor second pereopod fingers smooth near apex; propodus of pereopod 3 with ventral spines distributed along the margin............. pearsei

[Brazil: Maranhão]

\section{ACKNOWLEDGEMENTS}

We are grateful to Dr. Roberto Gomes de Freitas Berlinck (USP) for providing the ascidian specimens included in the present study. The material was collected during the project "Componentes da biodiversidade e seus caracteres metabólicos de ilhas do Brasil - uma abordagem integrada” funded by Fundação de Amparo à Pesquisa do Estado de São Paulo (FAPESP) under the number BIOTA/ BIOprospecTA grant 2013/50228-8. Special thanks go to Dr. Rosana Moreira da Rocha (UFPR) for providing a color photo of the ascidian used in this study, to Dr. Martin L. Christoffersen and MSc. Daniela Grangeiro (UFPB) for examining specimens of $P$. atlanticus deposited in the UFPB collection, to Dr. Marcos Tavares (MZUSP) for providing work space and access to the collection under his care. We also thank
Dr. Zdenek Duriš and an anonymous reviewer for providing valuable comments that greatly improved the originally submitted manuscript.

\section{References}

Abele, L.G. 1971. A new species of Periclimenaeus Borradaile, 1915 (Crustacea: Decapoda: Palaemonidae) from the northeastern Gulf of Mexico. Tulane Studies in Zoology and Botany, 17: $38-40$.

Abele, L.G. and Kim, W. 1986. An illustrated guide to the marine decapod crustaceans of Florida. Tallahassee, State of Florida Department of Environmental Regulation (Technical Series, 8), 760p.

Boone, P.L. 1930. New decapod and isopod crustaceans from Gonave Bay, Haiti. Zoologica, New York, 12: 41-53.

Borradaile, L.A. 1915. Notes on Carides. The Annals and Magazine of Natural History, Series 8, 15: 205-213.

Bruce, A.J. 1995. A synopsis of the Indo-West Pacific genera of the Pontoniinae (Crustacea: Decapoda: Pontoniinae). Theses Zoologicae, 25: 1-172.

Bruce, A.J. 2006. Periclimenaeus nielbrucei sp. nov. (Crustacea: Decapoda: Pontoniinae), a new sponge associate from the Capricorn Islands, Queensland, with notes on related Periclimenaeus species. Zootaxa, 1224: 1-22.

Bruce, A.J. 2011. Periclimenaeus pulitzerfinali sp. nov. (Crustacea: Decapoda: Palaemonidae), a new pontoniine shrimp from East Africa. The Beagle, Records of the Museums and Art Galleries of the Northern Territory, 27: 113-121.

Bruce, A.J. 2012a. Periclimenaeus parkeri sp. nov. (Crustacea: Decapoda: Pontoniinae) from the Kimberley, Western Australia. Cahiers de Biologie Marine, 53: 289-298.

Bruce, A.J. 2012b. Notes on some Indo-Pacific Pontoniinae, 51. Periclimenaeus quadridentatus (Rathbun, 1906) and $P$. crassipes (Calman, 1939) (Decapoda, Pontoniinae), with the designation of $P$. calmani and P. serenei spp. nov. Crustaceana, 85: 513-531.

Bruce, A.J. 2012c. Periclimenaeus dactylodon sp. nov. (Decapoda: Pontoniinae), from Heron Island, Queensland, Australia. Zootaxa, 3436: 51-60.

Bruce, A.J. 2013. Notes on some Indo-Pacific Pontoniinae, LIII. Periclimenaeus species from the Hawaiian region. Crustaceana, 86: $1605-1622$.

Bruce, A.J. 2014a. Periclimenaeus species (Crustacea: Decapoda: Pontoniinae) from Hawaii. Zootaxa, 3754: 461-472.

Bruce, A.J. 2014b. Periclimenaeus colemani sp. nov. (Crustacea; Palaemonidae; Pontoniinae) from Heron island, Queensland. Zootaxa, 3774: 258-264.

Bruce, A.J. 2014c. Periclimenaeus denticulodigitus sp. nov. (Crustacea: Decapoda: Palaemonidae: Pontoniinae), from Heron Island, Queensland, Australia. Zootaxa, 3753: 71-78.

Bruce, A.J. 2014d. Notes on some Indo-Pacific Pontoniinae, LIV. New Periclimenaeus species (Decapoda, Pontoniinae), from Cartier Island Reef, Western Australia. Crustaceana, 87: 64-82.

Cardoso, I.A. and Young, P.S. 2007. Caridea (Crustacea, Decapoda: Disciadidae, Palaemonidae, Processidae, Rhynchocinetidae) from Rocas Atoll including two new species of Periclimenaeus 
Borradaile, 1951. Arquivos do Museu Nacional, Rio de Janeiro, 65: 277-337.

Chace, F.A. 1972. The shrimps of the Smithsonian-Bredin Caribbean Expeditions with a summary of the West Indian shallow-water species (Crustacea: Decapoda: Natantia). Smithsonian Contribution to Zoology, 98: 1-179.

Coelho, P.A.; Almeida, A.O.; Souza-Filho, J.F.; Bezerra, L.E.A. and Giraldes, B.W. 2006. Diversity and distribution of the marine and estuarine shrimps (Dendrobranchiata, Stenopodidea and Caridea) from north and northeast Brazil. Zootaxa, 1221: 41-62.

Coelho, P.A. and Ramos, M.A. 1972. A constituição e a distribuição da fauna de decápodos do litoral leste da América do Sul entre as latitudes de $5^{\circ} \mathrm{N}$ e $39^{\circ} \mathrm{S}$. Trabalhos Oceanográficos $d a$ Universidade Federal de Pernambuco, 13: 133-236.

De Grave, S. and Anker, A. 2017. An annotated checklist of marine caridean and stenopodidean shrimps (Malacostraca: Decapoda) of the Caribbean coast of Panama. Nauplius, 25: e2017015.

De Grave, S. and Fransen, C.H.J.M. 2011. Carideorum catalogus: the recent species of the dendrobranchiate, stenopodidean, procarididean and caridean shrimps (Crustacea: Decapoda). Zoologische Mededelingen, 89: 195-589.

Dobson, N.C.; Johnson, M.L. and De Grave, S. 2016. Insights into the morphology of symbiotic shrimp eyes (Crustacea, Decapoda, Palaemonidae); the effects of habitat demands. PeerJ, 4: e1926.

Ďuriš, Z.; Horká, I. and Al-Horani, F. 2011. Periclimenaeus echinimanus sp. nov. (Crustacea: Decapoda: Pontoniinae), a new species from the Gulf of Aqaba, Red Sea. Zootaxa, 2983: 57-68.

Ďuriš, Z.; Horká, I. and Sandford, I. 2009. Periclimenaeus pectinidactylus n. sp. (Crustacea: Decapoda: Pontoniinae) from the Belizean Barrier Reef, Caribbean Sea. Zootaxa, 2130: 31-40.

Fransen, C.H.J.M. 2006. On Pontoniinae (Crustacea, Decapoda, Palaemonidae) collected from ascidians. Zoosystema, 28: 713-746.

Hay, W.P. 1917. Preliminary descriptions of five new species of crustaceans from the coast of North Carolina. Proceedings of the Biological Society of Washington, 30: 71-74.

Holthuis, L.B. 1951. A general revision of the Palaemonidae (Crustacea Decapoda Natantia) of the Americas. I. The subfamilies Euryrhynchinae and Pontoniinae. Allan Hancock Foundation Publications, Occasional Papers, Los Angeles, 11: $1-332$.

Pachelle, P.P.G.; Leray, M.; Anker, A. and Lasley, R. 2018. Five new records of marine shrimps (Decapoda: Caridea,
Stenopodidea) from the Caribbean coast of Panama. Zootaxa, 4438: $128-136$.

Rafinesque, C.S. 1815. Analyse de la nature ou tableau de l'univers et des corps organisés. Palermo (self-published), 223p.

Ramos-Porto, M. 1980. Estudo ecológico da região de Itamaracá, Pernambuco, Brasil. VII. Crustáceos Decápodos Natantes. Trabalhos Oceanográficos da Universidade Federal de Pernambuco, 15: 277-309.

Ramos-Porto, M. and Coelho, P.A. 1990. Sinopse dos crustáceos decápodos brasileiros (Família Palaemonidae). Anais da Sociedade Nordestina de Zoologia, 3: 93-111.

Ramos-Porto, M. and Coelho, P.A. 1998. Malacostraca. Eucarida. Caridea (Alpheoidea excluded). p. 325-350. In: Young, P.S. (ed), Catalogue of Crustacea of Brazil. Rio de Janeiro, Museu Nacional. (Série Livros 6)

Ramos-Tafur, G.E and Lemaitre, R. 2017. A new species of shrimp of the genus Periclimenaeus Borradaile, 1915 (Decapoda: Caridea: Palaemonidae) from the southeastern Gulf of Mexico, including a key to the western Atlantic species of the genus. Zootaxa, 4303: 491-508.

Rathbun, M.J. 1901. Investigations of the Aquatic Resources and Fisheries of Porto Rico by the United States Fish Commission Steamer Fish Hawk in 1899. The Brachyura and Macrura of Porto Rico. Bulletin of the United States Fish Commission, 20: $1-127$.

Santana-Moreno, L.D.; De Grave, S. and Simões, N. 2013. New records of caridean shrimps (Decapoda: Caridea) from shallow water along the northern Yucatan peninsula coasts of México. Nauplius, 21: 225-238.

Schmitt, W.L. 1932. Appendix in Pearse, Inhabitants of certain sponges at Dry Tortugas. Carnegie Institute of Washington Publication, 435: 123-124.

Schmitt, W.L. 1936. Zoologische Ergebnisse einer Reise nach Bonaire, Curaçao und Aruba im Jahre 1930. No. 16. Macruran and anomuran Crustacea from Bonaire, Curaçao and Aruba. Zoologische Jahrbücher. Abteilung für Systematik, Ökologie und Geographie der Tiere, 67: 363-378.

Souza, J.A.F.; Schwamborn, R.; Barreto, A.V.; Farias, I.D.; Fernandes, L.M.G. and Coelho, P.A. 2011. Marine and estuarine shrimps (Dendrobranchiata, Stenopodidea, and Caridea), of Pernambuco State (Brazil) and northeastern Brazilian oceanic islands. Atlântica, Rio Grande, 33: 33-63.

Vieira, R.R.R.; Ferreira, R.S. and D’Incao, F. 2012. Pontoniinae (Crustacea: Decapoda: Caridea) from Brazil with taxonomic key. Zootaxa, 3149: 1-38.

Young, P.S. 1986. Análise quantitativa e qualitativa da fauna associada a corais hermatípicos (Coelenterata, Scleractinia) nos recifes de João Pessoa, PB. Revista Brasileira de Biologia, 46: 99-126. 